\title{
Graphene materials as 2D non-viral gene transfer vector platforms
}

DOI:

10.1038/gt.2016.79

\section{Document Version}

Accepted author manuscript

Link to publication record in Manchester Research Explorer

\section{Citation for published version (APA):}

Kostarelos, K., Vincent, M., \& De Lazaro Del Rey, I. (2017). Graphene materials as 2D non-viral gene transfer vector platforms. Gene Therapy, 24, 123-132. https://doi.org/10.1038/gt.2016.79

\section{Published in:}

Gene Therapy

\section{Citing this paper}

Please note that where the full-text provided on Manchester Research Explorer is the Author Accepted Manuscript or Proof version this may differ from the final Published version. If citing, it is advised that you check and use the publisher's definitive version.

\section{General rights}

Copyright and moral rights for the publications made accessible in the Research Explorer are retained by the authors and/or other copyright owners and it is a condition of accessing publications that users recognise and abide by the legal requirements associated with these rights.

\section{Takedown policy}

If you believe that this document breaches copyright please refer to the University of Manchester's Takedown Procedures [http://man.ac.uk/04Y6Bo] or contact uml.scholarlycommunications@manchester.ac.uk providing relevant details, so we can investigate your claim.

\section{OPEN ACCESS}



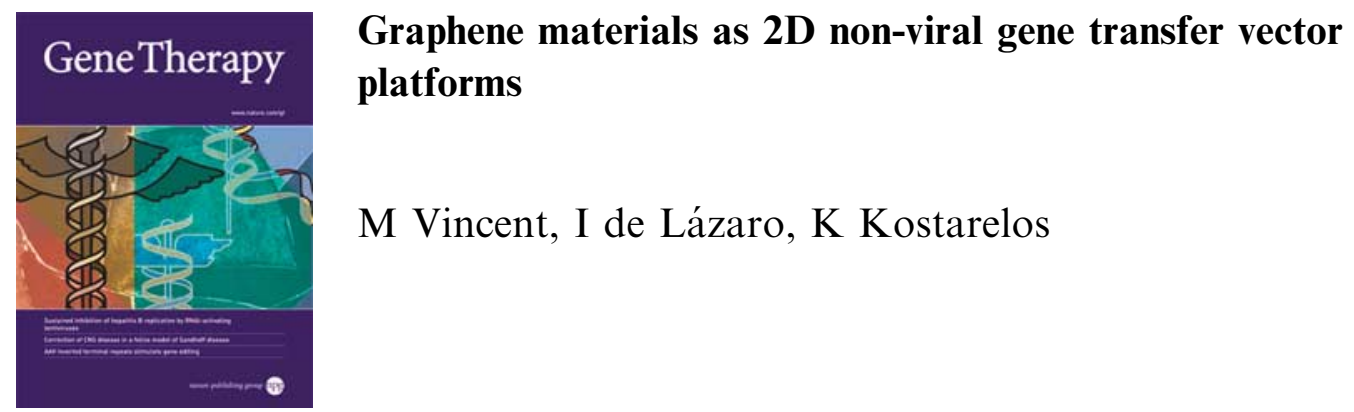

M Vincent, I de Lázaro, K Kostarelos

Cite this article as: $\mathrm{M}$ Vincent, I de Lázaro, K Kostarelos, Graphene materials as 2D non-viral gene transfer vector platforms, Gene Therapy accepted article preview 22 November 2016; doi: 10.1038/gt.2016.79.

This is a PDF file of an unedited peer-reviewed manuscript that has been accepted for publication. NPG are providing this early version of the manuscript as a service to our customers. The manuscript will undergo copyediting, typesetting and a proof review before it is published in its final form. Please note that during the production process errors may be discovered which could affect the content, and all legal disclaimers apply.

Received 5 May 2016; revised 25 September 2016; accepted 13 October 2016; Accepted article preview online 22 November 2016 


\title{
Graphene materials as 2D non-viral Gene Transfer Vector Platforms
}

\author{
Mélissa Vincent^^, Irene de Lázaro^ and Kostas Kostarelos* \\ Nanomedicine Laboratory, Faculty of Medical \& Human Sciences and National Graphene Institute, AV Hill Building, \\ University of Manchester, United Kingdom
}

* Correspondence should be addressed to: kostas.kostarelos@manchester.ac.uk

^These authors contributed equally to this work

\begin{abstract}
Advances in genomics and gene therapy could offer solutions to many diseases that remain incurable today, however one of the critical reasons halting clinical progress is due to the difficulty in designing efficient and safe delivery vectors for the appropriate genetic cargo. Safety and largescale production concerns counter-balance the high gene transfer efficiency achieved with viral vectors, while non-viral strategies have yet to become sufficiently efficient. The extraordinary physicochemical, optical and photothermal properties of graphene-based materials (GBMs) could offer two-dimensional (2D) components for the design of nucleic acid carrier systems. We discuss here such properties and their implications for the optimization of gene delivery. While the design of such vectors is still in its infancy, we provide here an exhaustive and up-to-date analysis of the studies that have explored GBMs as gene transfer vectors, focusing on the functionalization strategies followed to improve vector performance and on the biological effects attained.
\end{abstract}

Keywords: nanotechnology, nanomedicine, drug delivery, nucleic acid, carbon nanomaterials 


\section{Introduction}

Ever since the deciphering of the genetic code, increasing knowledge in the genetic etiology of numerous ailments together with remarkable advances in molecular biology has opened new therapeutic possibilities for otherwise incurable diseases. One of the main roadblocks holding back more significant and widespread clinical success for gene therapy is the development of efficient and safe carriers, able to deliver a genetic cargo to target cells and tissues. Due to millions of years of evolution in optimizing transport of their genomes to mammalian cells, viruses continue to be the most efficient carriers to deliver a genetic payload. This is reflected by the fact that almost $70 \%$ of all gene therapy clinical trials performed to date have used viral vectors ${ }^{1}$. However, significant efforts to avoid random genomic integration and diminish immunogenicity have yet failed to completely address the safety concerns raised by the use of these powerful biological carriers. Limited capacity to accommodate very long nucleic acids, together with their elevated production costs and challenging batch-to-batch variation on upscaling, further challenge the widespread adoption of these vector systems ${ }^{2}$.

In contrast, the development of non-viral vectors that are in principle safer and more adaptable to upscale has so far been mainly hampered by compromised transfer and expression efficiency. Despite the many different materials explored as components of non-viral vectors, including cationic lipids, polymers, dendrimers and polysaccharides ${ }^{3}$, none has managed to match the biological efficacy obtained with viral vectors. In addition, the excess of positive charges required to complex nucleic acid cargos and facilitate endosomal escape intracellularly is often the cause of unwanted cytotoxicity and inflammation ${ }^{4}$.

The recent discovery of two-dimensional (2D), mono-atomic carbon-based graphene materials ${ }^{5-7}$ and their chemical derivatives ${ }^{8}$, has added a new range of options for the design and fabrication of non-viral gene delivery vectors. In this article, we first analyze the remarkable physicochemical, optical, and photothermal properties that have raised the interest on graphene based materials (GBMs) as gene delivery vectors to then provide a comprehensive review of the studies published to date on this topic (summarized in Table 1). Special attention will be paid to the surface functionalization and modification strategies performed to GBMs in order to optimize them as gene delivery vectors, as well as to the biological activity and efficacy achieved.

\section{What can GBMs offer as gene delivery platforms?}

Graphene is a 2D material which consists of a single atomic layer of sp2 hybridized carbon atoms organized in a honeycomb lattice. Its unique physical, thermal and electrical abilities have generated great interest in several research areas such as physics and electronics since its discovery in $2004^{6}$. Its oxidized form, graphene oxide (GO) retains these remarkable properties, as well as offer facile aqueous dispersibility and biocompatibility that make it a better candidate for biomedical applications ${ }^{9}$. Altogether GBMs possess many properties that fit the numerous requirements to the design of non-viral vectors for gene delivery, which will be analyzed here, and summarized in Figure 1. 
Facile and versatile chemical functionalization. GBMs are able to establish strong covalent binding through carbon rehybridization from sp2 to sp3 hybrid orbital state ${ }^{10}$. In the particular case of $\mathrm{GO}$, the presence of epoxides, carbonyls and hydroxyls offers further derivation possibilities such as amidation through epoxy ring opening and esterification ${ }^{11}$. Most of such reactions take place in the presence of coupling agents such as 1-Ethyl-3-(3-dimethylaminopropide)carbodiimide (EDC) or N-hydroxysuccinimide (NHS). Additionally, GBMs can not only act as electron donating ligand to establish $\pi-\pi$ stacking but also as electron acceptor in the case of physisorption which mostly occurs via electrostatic interactions, Van der Waals forces and hydrogen bonds ${ }^{12}$. This variety of chemical routes therefore offers numerous possibilities for the functionalization of GBMs in order to (a) tailor their pharmacokinetic properties and enhance their biocompatibility ${ }^{13}$, (b) engraft cationic molecules to increase nucleic acid (NA) loading efficiency, (c) incorporate water insoluble drugs or molecules that are subject to drug-resistance mechanisms ${ }^{14}$ and (d) incorporate imaging agents ${ }^{15}$.

Ability to condense genetic material. The capability of GBMs to bind NA has been widely reported in the case of graphene-based DNA biosensors ${ }^{16}$. Isothermal titration calorimetry experiments between graphene and nucleobases revealed that guanine presented the highest interaction energy followed by adenine, cytosine and thymine ${ }^{17}$. Moreover, GO has proven able to load both single-stranded DNA and RNA despite its overall negative charge thanks to hydrophobic and $\pi-\pi$ stacking interactions between the ring structures present in NA nucleobases and the GO hexagonal carbon lattice ${ }^{18,19}$. On the other side, the adsorption of double-stranded NA onto GO flakes is thought to be more complex due to its hydrophilic external structure and less availability of NA bases trapped within the double helix structure ${ }^{20}$. However, other type of driving forces such as hydrogen binding and Van der Waals forces have been proposed on top of $\pi-\pi$ stacking interactions to promote the interfacing between double-stranded DNA and GO carbon rings ${ }^{21,22}$. It has also been suggested that partial deformation of the NA double helix could favor adsorption processes onto the surface of $\mathrm{GO}^{21}$. Additionally, environmental conditions such as high salt concentrations and low $\mathrm{pH}$ have been demonstrated to greatly improve the binding ability of double stranded NA onto $\mathrm{GO}^{23}$.

Protection of nucleic acid from enzymatic degradation. Several studies have shown the ability of GBMs to prevent NA from enzymatic digestion. Simple experiments performed in the presence of DNAse I showed complete digestion of single stranded DNA (ssDNA) after 60 minute incubation whilst no degradation was reported in the case of the GO:ssDNA nanocomplexes in the same conditions ${ }^{24}$. Tang et al presented similar results in the case of graphene:ssDNA constructs and confirmed their observations thanks to anisotropy analysis of fluorescently labeled SsDNA ${ }^{25}$. However, this protective effect seems more controversial and subject to debate in the case of double stranded NA. Lei et al demonstrated that this protective effect was highly dependent on salt concentrations in the case of double stranded NA and that it could be reversed by the addition of an anionic surfactant such as triton $\mathrm{X}-100^{23}$. In addition, enzymatic digestion by DNAse I and 
EcoR I has been shown to occur even if double stranded DNA was partially adsorbed onto GO whereas resistance to degradation by Exo III was reported at the same time ${ }^{21}$. Different hypothesis have been stated in the literature to explain the protective effect of nanoparticles such as gold and CNT over NA ${ }^{26,27}$. These include a conformational change in the helical structure that renders NA unrecognizable by enzyme binding pockets and steric hindrance due to the nanomaterial itself that thwarts nuclease digestion. Nevertheless, this effect remains poorly understood in the case of GBMs and further investigation is still required to precisely determine how environmental conditions - salt concentrations, $\mathrm{pH}$, mass ratio- impact or not the enzymatic digestion of both single and double-stranded NA.

Cellular internalization. The presence of GBMs in the intracellular compartments has been observed among others by Sasidharan et al thanks to confocal microscopy ${ }^{28}$ and Huang and co-workers via surfaceenhanced Raman spectroscopy ${ }^{29}$. However, the underlying mechanisms of cellular internalization of GBMs remain enigmatic and several pathways have been proposed. The two main working hypotheses include phagocytosis and clathrin-mediated endocytosis ${ }^{30,31}$ but the possibility of membrane translocation through a "piercing effect" has also been revealed from computational studies ${ }^{32,33}$. Remarkably, photothermal effect due to the ability of graphene to absorb NIR light was suggested to enhance the transfection efficiency thanks to induced heating which locally disrupts the organization of the lipid bilayer cell membrane, hence rendering it more permeable and facilitating endosomal escape ${ }^{34}$.

Low toxicity. Even though GBM toxicology studies are still in their infancy and greatly vary depending on the features - lateral dimension, thickness, chemical modifications, colloidal dispersibility - of the material investigated, preliminary results suggest that GBMs induce lower cytotoxicity than carbon nanotubes and that adequate functionalization increases their biocompatibility ${ }^{35}$. So far, GBMs have been reported to mainly accumulate in the lungs, liver and spleen. In most of the cases, no deleterious effects were described after intravenous, intraperitoneal or pulmonary administration of these materials. However, a meta-analysis of the studies published so far revealed the establishment of an inflammatory response in the lungs when the intravenously injected GBM had low functionalization degree and was administered at high doses for a long time of exposure ${ }^{36}$. Nonetheless, more in vivo data are still needed for an in-depth understanding of the mechanisms governing the body response to GBM.

\section{Strategies to optimize GBMs as gene delivery platform}

The performance of GBMs as delivery vectors can be improved by different strategies that optimize the loading and release of the NA, or allow the incorporation of other therapeutic or diagnostic agents, among others. Here, we review the most recurring strategies that have been proposed to transform bare GBMs into efficient and safe gene delivery vectors (Figure 2) and discuss the advantages and limitations of such modifications, compiled in Table 2. 
Covalent and non-covalent interactions with cationic polymers, dendrimers and polysaccharides. The engraftment of cationic polymers such as polyethylanimine (PEI) to the GBM surface has been investigated as a strategy to enhance gene transfection efficiency, thanks to the establishment of a cloud of positive charges around the material that favors the electrostatic interactions both with the NA and the cell membrane. In addition, the positive charges of PEI facilitate the release of the cargo from the endosome thanks to the "proton sponge" effect. The most common approach consists of the covalent engraftment of polyethylanimine (PEI) via EDC/ NHS chemistry onto both GO and reduced GO (rGO) flakes ${ }^{34,37-47}$. Noncovalent but electrostatic interactions have also been used to anchor PEI onto graphene nanoribbons $(\mathrm{GNR})^{48}, \mathrm{GO}^{49}$ and rGO/Au composites ${ }^{50}$. Thanks to the above properties, PEI has been used as a non-viral gene delivery vector on its own, however compromised by its cytotoxicity, especially at high molecular weight $(25 \mathrm{kDa})$ and high nitrogen-to-phosphate ratios ${ }^{51}$. Its combination with GBMs allows the use of low molecular weight PEI with comparable gene complexation efficiencies to that of the high molecular weight counterparts, therefore reducing its cytotoxicity ${ }^{52}$.

GBMs with covalently attached polyethylene glycol (PEG) have also been extensively studied for biomedical applications as such modification has shown to increase blood circulation time in vivo, enhance stability under physiological conditions as well as biocompatibility ${ }^{53}$. Exploiting this properties, Feng et al and Yin et al elaborated similar GO nanoplatforms covalently engrafted with both PEG and PEI which were able to effectively load EGFP-coding plasmid DNA (pDNA) ${ }^{34}$ and plasmid-based stat3 siRNA ${ }^{47}$ whilst observing satisfying physicochemical stability of the designed nanoconstructs. PEG has also been used to decorate graphene quantum dots (GQDs) ${ }^{54}, \mathrm{GO}^{41}$ and graphene/Au composite ${ }^{50}$ for the delivery of various nucleic acids. Interestingly, Zhang et al compared the loading efficiency of $\mathrm{rGO}$ and GO nanoplatforms after covalent functionalization with PEG. The study reported that the engraftment of PEG was able to restore the aqueous dispersibility of rGO whereas rGO-PEG exhibited better loading capacity and transfection efficacy in HeLa cells compared to GO-PEG. This finding was confirmed thanks to computational modelling and was attributed to the increased availability of aromatic domains in the case of $\mathrm{rGO}$, which facilitated $\pi-\pi$ stacking interactions between NA and the carbon lattice ${ }^{55}$.

Additionally, cationic dendrimers and polysaccharides have been used for similar purposes. Chitosan (CS), a positively charged linear polysaccharide was covalently linked to GO through EDC/NHS chemistry in order to improve colloidal dispersibility in PBS and cell culture medium, increasing transfection efficiency whilst inducing lower cytotoxicity ${ }^{56,57}$. CS is a well-known naturally occurring molecule which has been widely used as a gene/ drug nanocarrier and for the functionalization of nanoparticles in order to improve their aqueous dispersibility ${ }^{58}$. It has also been considered a promising alternative to PEI as it exhibits less cytotoxicity ${ }^{59}$. However, Bao et al reported much lower transfection efficacy with GO-CS:pDNA nanocomplexes compared to those based on PEI:pDNA alone, implying that the NA transfer efficiency of such vectors is yet to be optimized ${ }^{56}$. 
Lastly, polyamidoamine (PAMAM) dendrimers consist of a highly spherically ramified polymer which exhibit a biodegradable peptide backbone and a central core that can be filled with therapeutic molecules. PAMAM dendrimers have therefore been widely studied for biomedical applications due to their morphological similarities with spherical proteins, enhanced biocompatibility and easy structural control ${ }^{60}$. In the context of gene delivery, Liu et al engrafted PAMAM through 1,3 dipolar cycloaddition onto both graphene and GO in order to increase the stability of their nanoconstructs and improve transfection efficiency thanks to the electrostatic interactions occurring between PAMAM and NA ${ }^{61}$. Similarly, Yang and co-workers covalently linked PAMAM dendrimers thanks to EDC/NHS chemistry in order to improve delivery performances and decrease cytotoxicity ${ }^{62}$.

Functionalization with cell-penetrating peptides. In order to increase the cellular uptake of GBM nanoplatforms, membrane penetrating peptides or acids were added via various approaches. As an example, oleic acid, which exhibits a high affinity with the cell membrane and promotes its destabilization, was used to functionalize graphene and GO in combination with PAMAM dendrimers ${ }^{61}$. Additionally, the cationic cell penetrating peptide octaarginine was covalently engrafted onto GO flakes ${ }^{63}$ or non-covalently and together with a phospholipid-based amphiphilic polymer (PL-PEG) onto rGO by Imani et al in order to increase cellular uptake. Ren and co-workers adsorbed the membrane penetrating peptide PV7 to promote nuclear localization of the transfected pDNA ${ }^{42}$. In general, these systems demonstrated superior transfer efficiency compared to their respective bare materials. However, the ratio of cell penetrating peptide in the formulation has also demonstrated to have a significant impact in the stability of the system. Ren et al descried physical instability at high functionalization ratios that could jeopardize transfection efficiency.

Combination with other nanoparticles. The combination of GBMs with other nanoparticles has been investigated in order to increase transfection efficiency. Xu et al encapsulated gold nanoparticles (AuNP) and nanorods (AuNR) with GO thanks to self-assembly mechanisms via electrostatic interactions ${ }^{43}$. Interestingly, encapsulated AuNP exhibited improved transfection efficiency compared to encapsulated AuNR and GOPEI. This result was attributed to their smaller particle size and spherical structure together with the establishment of a GO hydrophilic shell that enhanced biocompatibility. In addition, Cheng and co-workers used graphene/ Au nanocomposite functionalized with PEG and PEI, showing an effective downregulation of $\mathrm{Bcl}-2$. The incorporation of gold nanoparticles was thought to improve photothermal effect upon NIR irradiation $^{50}$.

Introduction of cleavable links for tumor-specific targeting. Tumor-specific targeting has been achieved through the incorporation of chemical linkages responsive to the tumor microenvironment. Yang and coworkers synthesized organic-inorganic hybrid materials by decorating GO with poly(2-dimethylamino)ethyl methacrylate (PDMAEMA) thanks to surface initiated atom transfer radical polymerization ${ }^{64}$. This chemical process allowed the introduction of disulphide cleavable bonds between GO and PDMAEMA which enabled 
the release of the polymer complexed with pDNA under reducible conditions. Qin et al covalently engrafted doxorubicin onto GO-PEI-PEG using a MMP2-cleavable peptide linkage, consequently allowing the release of doxorubicin only in the presence of the enzyme, which is over expressed in cancer cells ${ }^{41}$.

\section{Promises and achievements of GBMs as gene delivery vectors}

It has been proposed that GBMs could make a difference as delivery platforms in a number of gene transfer-related applications. Here, we review those for which experimental data has already been shown (Figure 3) and highlight the promises that remain to be demonstrated.

Intracellular molecular sensing. The first studies that used GBMs to deliver a genetic payload into cells pursued the development of an intracellular molecular probe. Lu et al were pioneers in using nanoscale GO for such application ${ }^{24}$. Condensation to the modified GO sheets of a hairpin-shaped DNA molecular beacon (MB) recognizing the survivin transcript proved not only protection of the NA against degradation but also its intracellular delivery in HeLa cells. Importantly, the ability to hybridize to its mRNA target remained intact. The latter was demonstrated by the recovery of fluorescence upon hybridization, otherwise quenched in the hairpin conformation. Since survivin is a protein overexpressed in many cancers, and frequently associated to multidrug resistance ${ }^{65}$, this system could have potential applications in cancer diagnostics. Almost simultaneously, Wang and collaborators achieved the intracellular delivery of a DNA aptamer/GO nanocomplex in JB6 cells ${ }^{66}$. In this study, GO was proposed as a real-time biosensing platform in living cells. Upon complexation, GO was able to quench the fluorescence of the carboxyfluorescein-labeled aptamer. However, upon cellular internalization and thanks to the weak interactions governing the complex, the aptamer was able to bind its target, adenosine triphosphate (ATP), and release from the carbon lattice therefore recovering the fluorescent signal. In a different study, Dong et al similarly developed a method to detect microRNAs in single cells ${ }^{48}$. In this case, the delivery of a MB with high affinity for miR-21 proved more efficient when complexed to a PEI-GNR in comparison to other vectors such as PEI alone and PEIMWCNTs. The same group later developed a more sophisticated GQD-based system that not only allowed the intracellular imaging of miR-21 but also made it possible to track the internalization of the complex thanks to the strong fluorescent signal emitted by the vector ${ }^{54}$. Finally, Zhang and colleagues highlighted the superior performance of PEG-rGO as biosensing platform, compared to PEG-GO ${ }^{55}$.

Expression of exogenous genes. The forced expression of foreign genes encoded in pDNA cassettes is to date and by far the most exhaustively explored application of GBMs in the gene transfer field. Most of such studies do not surpass the proof-of-principle stage, assessing transgene expression but without therapeutic goals. They have explored a variety of functionalization strategies ${ }^{37,45,46,52,56,64}$, the conjugation to molecules that facilitate cell and nuclear internalization ${ }^{42,61,63}$ as well as the combination with other nanoparticles ${ }^{43}$, all already discussed in the previous section, in an attempt to increase the efficiency of gene transfer. However, 
it is difficult to establish direct comparisons between the results achieved by these studies given the numerous factors - e.g. type of GBM, lateral dimensions, type and molecular weight of PEI, transfection conditions, cell line used - that can have an impact in transfection efficiency and that are not always accurately described in the reports cited here.

Other more sophisticated studies have taken advantage of the interesting optical and photothermal properties of GBMs in order to offer additional features to the gene transfer process. Kim and colleagues not only demonstrated the capacity of covalently linked GO-BPEI to force the expression of a luciferase encoding pDNA in two different cancer cell lines, which was superior to that of BPEI low molecular weight alone and comparable to that of BPEI high molecular weight but with reduced cytotoxicity ${ }^{38}$. The authors also made use of the photoluminescent properties of GO-BPEI, which allowed them to follow the GO-BEPI/pDNA complexes during transfection by confocal microscopy and to confirm that carrier and nucleic acid payload travelled together inside the cells, via complexation with a fluorescently labeled pDNA. This strategy could be therefore useful for bioimaging and internalization studies. The capacity of GBMs to produce heat upon NIR irradiation has also been explored by this and other groups in order to achieve spatially and/or temporally controlled gene transfer ${ }^{34,39}$. Such a strategy could be of great interest in the development of targeted therapies, the nucleic acid being preferentially delivered at the irradiated area thanks to the facilitation of endosomal escape by local heat.

In spite of the numerous studies exploring GBM-mediated gene transfer, most of them have been limited to the delivery of a reporter gene as a proof-of-concept. Only two recent reports have attempted to express genes with either therapeutic purposes or aiming to unchain a change in cell fate. Paul and colleagues designed a hydrogel formulation able to release PEI-GO/pDNA complexes, where the cassette encoded the vascular endothelial growth factor (VEGF) gene ${ }^{40}$. In vitro, such strategy proved able to efficiently transfect rat cardiomyoblasts, which subsequently produced functionally active VEGF protein. When exposed to the transgenic protein, the proliferation rate of HUVEC endothelial cells increased. In vivo, $\mathrm{PEI}-\mathrm{GO} / \mathrm{pDNA}{ }^{\mathrm{VEGF}}$ complexes where injected in the peri-infarcted area in a rat model of myocardial infarction, leading to a significant increase in the number of microcapillaries in the area of injection, together with a reduction in scar size and an improvement in cardiac function compared to controls. Choi et al have not only been first to demonstrate mRNA complexation and efficient delivery by a GO-PEI construct, but also to report the generation of putative induced pluripotent stem (iPS) cells following such a strategy ${ }^{67}$. Delivery of synthetic mRNA or total RNA extracted from pluripotent stem cells generated cell colonies that expressed pluripotency markers, showed a pattern of DNA methylation similar to that of pluripotent cells and were able to differentiate in vitro towards all three germ-layers. Nevertheless, it remains to be proven whether such cells are bona fide pluripotent stem cells, i.e. able to contribute to all tissues in an adult organism.

Finally, foreign gene expression has not only been achieved when GBMs were used as delivery vectors in aqueous suspension, but also when prepared as cell culture substrates. GO matrixes were able to adsorb PEI/pDNA complexes, which were then gradually released and internalized in the cells cultured on such surfaces ${ }^{49}$. As the substrates can be prepared with different patterns that allow or not the adsorption of 
$\mathrm{PEI} / \mathrm{pDNA}$ complexes, this strategy offers spatial control over gene transfer and therefore could be useful in the preparation of genetically different cell populations for the investigation of cell-cell interactions.

Gene silencing. Another goal frequently pursued in gene therapy is the silencing or downregulation of genes abnormally overexpressed in a pathological condition. Therefore GBMs have also been tested for the delivery of siRNAs and miRNAs. Tripathi et al used a PEI-GO construct to first deliver a GFP-encoding pDNA and, 3 hours later, silence its expression by the delivery of an anti-GFP siRNA with the same vector. Under optimal conditions, the knockdown reached levels of $70 \%$, as measured by fluorescence intensity ${ }^{46}$. Encouragingly, a similar GO-PEI:siRNA complex has been recently reported by Huang et al to efficiently downregulate its intracellular target CXCR4, a chemokine receptor strongly associated to cancer metastasis. This effect reduced the migratory capacity of cancer cells in a wound healing assay ${ }^{68}$. Dong et al explored the possibility of delivering two anti-sense probes against different targets - miR-21and survivin - in the same vector, which resulted in a synergistic effect against the growth of HeLa cancer cells ${ }^{54}$.

As in the case of foreign gene expression, the photothermal properties of GBMs can also enhance siRNA delivery. Following this strategy, Feng and collaborators optimized the intracellular internalization of a siRNA against the proto-oncogene Polo-like kinase 1 (Plk1), which resulted in significant downregulation of the target at the mRNA and protein levels ${ }^{34}$. However, the enhancement of siRNA intracellular trafficking is not the only benefit that the photothermal properties of GBMs can offer. Cheng et al proposed the combination of siRNA delivery and photothermal ablation as a potential anti-cancer strategy ${ }^{50}$. Their work demonstrated efficient siRNA delivery mediated by a PEG-PEI-rGO/Au vector, which resulted in the downregulation of the anti-apoptotic protein $\mathrm{Bcl}-2$ and, separately, a significant decrease in cell viability when cells were exposed to the vector in the presence of NIR irradiation. Although the synergy of gene silencing and thermal ablation remained unaddressed in this study, it was later confirmed by a different group through a similar strategy. An anit-Stat3 siRNA was delivered by a GO-PEI-PEG vector administered intratumorally, and together with NIR irradiation, in a mouse model of malignant melanoma ${ }^{47}$. While the administration of the GO-PEI-PEG vectors in the absence of siRNA but with NIR irradiation already resulted in tumor regression, the best results were achieved when combined with Stat3 downregulation.

A different strategy aimed to increase cytotoxicity against cancer cells is the combination of gene silencing and drug delivery. Such approach was first explored with the simultaneous delivery of the anticancer drug doxorubicin and a siRNA targeted against Bcl-2, which is often linked to multidrug resistance, in a PEI-GO vector. The synergy of both therapies was confirmed ${ }^{69}$. In Zhi et al's work, a similar rationale was followed with a PEI-PSS-Go carrier for anti-miR-21 siRNA and the anticancer drug adriamycin ${ }^{44}$. When adryamicin-resistant MCF7 cells were exposed to the drug delivered by the vector, their viability was significantly decreased. Noticeably, the drug alone was not effective at all, which confirmed the ability of the carrier to overcome drug resistance mechanisms developed by malignant cells. In addition, the most dramatic reduction in cell viability was achieved when drug and siRNA were concomitantly delivered, which highlights the encouraging potential of combined therapies. 
Theranostic platforms. Owing once again to its large surface area and the variety of functional groups that can be created on it, it has been possible to design GBM carriers that not only incorporate nucleic acids and drugs for combined therapies, but also encompass imaging contrast agents and therefore serve both as therapeutic and diagnostic tools. Wang and colleagues developed a multifunctional vector based on chitosan and $\mathrm{rGO}$ that incorporated SPIO nanoparticles as MRI contrast agents, the anticancer drug doxorubicin and a reporter pDNA encoding a fluorescent protein ${ }^{57}$. In vitro, this vector exhibited higher cytotoxicity than doxorubicin alone, while gene expression was also confirmed but did not reach the levels of a benchmark transfection reagent. Upon intraperitoneal (i.p.) and intravenous (i.v.) administration, the complexes were preferentially extravasated in the tumor thanks to the enhanced permeation and retention (EPR) effect and consequently no off-target biodistribution of the pDNA or drug was observed. Ex vivo, this vector also proved as an efficient MRI contrast agent. Qin et al also advocated for a tumor-targeted theranostic tool, this time by anchoring doxorubicin via a MMP2 cleavable link ${ }^{41}$. The release of the drug from the carrier in cancer cells, in which MMP2 is highly overexpressed, allowed the recovery of its intrinsic fluorescence and could therefore complement the cytotoxic properties of the drug with a method for tumor cell imaging. In non-cancerous cells, the drug remained linked to the vector and no fluorescence was emitted. microRNAs, chemotherapy and imaging agents have also been combined thanks to a gadolinium-functionalized GO (Gd-GO) construct that incorporated the anticancer drug epirubicin and Let- $7 \mathrm{~g}$ miRNA ${ }^{62}$. Let-7g is downregulated in a number of cancers and therefore its concomitant delivery with epirubicin holds great potential as a combined anticancer therapy. In support of this hypothesis, the highest levels of in vitro cytotoxicity were achieved when both the drug and the miRNA were incorporated in the vector, as opposed to those formulations that included only one of the two. In vivo, a similar Gd-GO composite was internalized by brain tumor cells upon intravenous administration and blood brain barrier disruption. However, the investigation of cytotoxic effects and tumor regression is yet to be addressed.

\section{Future perspectives}

A variety of functionalization routes have been investigated in order to optimize gene loading efficiency and intracellular release of NA when using GBMs as gene delivery vectors. However, the poor characterization of such constructs combined with the lack of comparative studies make it difficult to establish a reliable link between the features of the GBMs nanoplatform -type of GBM, dimensions, thickness, functionalization- and the observed biological effect. Moreover, the underlying mechanisms of cellular internalization of GBMs and NA release within the cytoplasm remain poorly explored. Here again, it is important to mention that the properties of the material used can greatly influence the cellular uptake of the nanocomplexes and consequently impact the transfection efficiency. There is therefore a need for more systematic studies able to make the relationship between the physicochemical and structural properties of the designed nanoconstructs, the GBMs/ cell interface and the biological outcomes shown in vitro and in vivo. 
Remarkably, only four out of the twenty-seven studies using GBMs to deliver a genetic payload published so far have provided data on in vivo models ${ }^{40,45,57,62}$, one of them limited to the injection of the material at the one-cell stage of zebrafish embryos. Therefore, one of the main challenges ahead in order to validate these materials as gene delivery vectors is to confirm whether their encouraging in vitro performance stands in the in vivo setup. Our attention should be also drawn to the fact the totality of the studies reviewed here have tested the ability of GBMs to transfect dividing cells. Considering that many gene therapy applications will involve the transfer of genetic payloads to post-mitotic cells (i.e. skeletal myofibers, neurons, cardiomyocytes), the capacity of GBMs to efficiently transfect genetic materials in the absence of cell division should be promptly investigated.

In conclusion, the use of GBMs as NA nanocarriers is still a very nascent field but has nonetheless shown encouraging preliminary results in numerous proof-of-concept studies. The facile and versatile functionalization of GBMs combined to their unique morphological properties and biological behavior should therefore pave the way for a new generation of non-viral gene delivery vectors.

\section{Acknowledgements}

This work was partially supported by the Horizon 2020 RTD Framework Programme, Graphene Core1 project (H2020SGA-RIA-696656-2014-20). Melissa Vincent is the recipient of the Louis Wong Hak Wood Presidential Doctoral Scholarship in Graphene and Biomedical Research at the Faculty of Biology, Medicine and Health, University of Manchester.

\section{Additional information}

Competing financial interests: The authors declare no competing financial interests. 


\section{FIGURE LEGENDS}

Figure 1. Opportunities offered by GBMs for the delivery of genetic payloads. The physicochemical properties of GBMs offer several advantages at the Vector Design (a), but also to optimize biodistribution upon administration (b) and at the vector-cell interface level (c).

Figure 2. Modification strategies to optimize GBMs as non-viral vector platforms. Numerous strategies are available to enhance the performance of GBMs as gene delivery vectors. These include the incorporation of cationic moieties to increase nucleic acid loading, cell penetrating peptides or acids to enhance cellular internalization and drug and/or imaging agents to build theranostic systems.

Figure 3. Published work using GBMs as platforms for nucleic acid delivery. All the studies described today have been classified according to three types of applications: gene silencing, exogenous gene expression and molecular sensing.

Table 1. Studies using GBMs for nucleic acid transport.

Table 2. Advantages and limitations of different GBMs modification strategies. 


\section{References}

1. Vectors used in gene therapy clinical trials. Journal of Gene Medicine 2015. Available online at http://www.abedia.com/wiley/vectors.php (Accessed January 2016).

2. Liu YP, Berkhout B. miRNA cassettes in viral vectors: problems and solutions. Biochimica et biophysica acta 2011; 1809: 732-745.

3. Yin H, Kanasty RL, Eltoukhy AA, Vegas AJ, Dorkin JR, Anderson DG. Non-viral vectors for gene-based therapy. Nature reviews Genetics 2014; 15: 541-555.

4. Hunter AC. Molecular hurdles in polyfectin design and mechanistic background to polycation induced cytotoxicity. Advanced drug delivery reviews 2006; 58: 1523-1531.

5. Novoselov KS, Geim AK, Morozov SV, Jiang D, Zhang Y, Dubonos SV et al. Electric field effect in atomically thin carbon films. Science 2004; 306: 666-669.

6. Geim AK, Novoselov KS. The rise of graphene. Nature materials 2007; 6: 183-191.

7. Geim AK. Graphene: Status and Prospects. Science 2009; 324: 1530-1534.

8. Park S, Ruoff RS. Chemical methods for the production of graphenes. Nat Nanotechnol 2009; 4: 217224.

9. Bitounis $\mathrm{D}$, Ali-Boucetta $\mathrm{H}$, Hong $\mathrm{BH}$, Min DH, Kostarelos K. Prospects and challenges of graphene in biomedical applications. Advanced materials 2013; 25: 2258-2268.

10. Chua CK, Pumera M. Covalent chemistry on graphene. Chemical Society reviews 2013; 42: 32223233.

11. Dreyer DR, Park S, Bielawski CW, Ruoff RS. The chemistry of graphene oxide. Chemical Society reviews 2010; 39: 228-240.

12. Yan L, Zheng YB, Zhao F, Li S, Gao X, Xu B et al. Chemistry and physics of a single atomic layer: strategies and challenges for functionalization of graphene and graphene-based materials. Chemical Society reviews 2012; 41: 97-114.

13. Yang K, Wan J, Zhang S, Zhang Y, Lee ST, Liu Z. In vivo pharmacokinetics, long-term biodistribution, and toxicology of PEGylated graphene in mice. ACS nano 2011; 5: 516-522.

14. Liu Z, Robinson JT, Sun X, Dai H. PEGylated nanographene oxide for delivery of water-insoluble cancer drugs. Journal of the American Chemical Society 2008; 130: 10876-10877.

15. Sun X, Liu Z, Welsher K, Robinson JT, Goodwin A, Zaric S et al. Nano-Graphene Oxide for Cellular Imaging and Drug Delivery. Nano research 2008; 1: 203-212. 
16. Lu CH, Yang HH, Zhu CL, Chen X, Chen GN. A graphene platform for sensing biomolecules. Angewandte Chemie 2009; 48: 4785-4787.

17. Varghese N, Mogera U, Govindaraj A, Das A, Maiti PK, Sood AK et al. Binding of DNA nucleobases and nucleosides with graphene. Chemphyschem : a European journal of chemical physics and physical chemistry 2009; 10: 206-210.

18. Patil AJ, Vickery JL, Scott TB, Mann S. Aqueous Stabilization and Self-Assembly of Graphene Sheets into Layered Bio-Nanocomposites using DNA. Advanced materials 2009; 21: 3159-+.

19. Cui L, Chen ZR, Zhu Z, Lin XY, Chen X, Yang CJ. Stabilization of ssRNA on Graphene Oxide Surface: An Effective Way to Design Highly Robust RNA Probes. Anal Chem 2013; 85: 2269-2275.

20. He SJ, Song B, Li D, Zhu CF, Qi WP, Wen YQ et al. A Graphene Nanoprobe for Rapid, Sensitive, and Multicolor Fluorescent DNA Analysis. Adv Funct Mater 2010; 20: 453-459.

21. Tang LH, Chang HX, Liu Y, Li JH. Duplex DNA/Graphene Oxide Biointerface: From Fundamental Understanding to Specific Enzymatic Effects. Adv Funct Mater 2012; 22: 3083-3088.

22. Zhao XC. Self-Assembly of DNA Segments on Graphene and Carbon Nanotube Arrays in Aqueous Solution: A Molecular Simulation Study. J Phys Chem C 2011; 115: 6181-6189.

23. Lei H, Mi L, Zhou X, Chen J, Hu J, Guo S et al. Adsorption of double-stranded DNA to graphene oxide preventing enzymatic digestion. Nanoscale 2011; 3: 3888-3892.

24. Lu CH, Zhu CL, Li J, Liu JJ, Chen X, Yang HH. Using graphene to protect DNA from cleavage during cellular delivery. Chem Commun 2010; 46: 3116-3118.

25. Tang Z, Wu H, Cort JR, Buchko GW, Zhang Y, Shao Y et al. Constraint of DNA on functionalized graphene improves its biostability and specificity. Small 2010; 6: 1205-1209.

26. Seferos DS, Prigodich AE, Giljohann DA, Patel PC, Mirkin CA. Polyvalent DNA nanoparticle conjugates stabilize nucleic acids. Nano letters 2009; 9: 308-311.

27. Wu YR, Phillips JA, Liu HP, Yang RH, Tan WH. Carbon Nanotubes Protect DNA Strands during Cellular Delivery. ACS nano 2008; 2: 2023-2028.

28. Sasidharan A, Panchakarla LS, Chandran P, Menon D, Nair S, Rao CNR et al. Differential nano-bio interactions and toxicity effects of pristine versus functionalized graphene. Nanoscale 2011; 3: 2461-2464.

29. Huang J, Zong C, Shen H, Liu M, Chen BA, Ren B et al. Mechanism of Cellular Uptake of Graphene Oxide Studied by Surface-Enhanced Raman Spectroscopy. Small 2012; 8: 2577-2584.

30. Mu QX, Su GX, Li LW, Gilbertson BO, Yu LH, Zhang Q et al. Size-Dependent Cell Uptake of ProteinCoated Graphene Oxide Nanosheets. Acs Appl Mater Inter 2012; 4: 2259-2266. 
31. Yue H, Wei W, Yue ZG, Wang B, Luo NN, Gao YJ et al. The role of the lateral dimension of graphene oxide in the regulation of cellular responses. Biomaterials 2012; 33: 4013-4021.

32. Tu YS, Lv M, Xiu P, Huynh T, Zhang M, Castelli M et al. Destructive extraction of phospholipids from Escherichia coli membranes by graphene nanosheets. Nat Nanotechnol 2013; 8: 594-601.

33. Li YF, Yuan HY, von dem Bussche A, Creighton M, Hurt RH, Kane AB et al. Graphene microsheets enter cells through spontaneous membrane penetration at edge asperities and corner sites. $P$ Natl Acad Sci USA 2013; 110: 12295-12300.

34. Feng LZ, Yang XZ, Shi XZ, Tan XF, Peng R, Wang J et al. Polyethylene Glycol and Polyethylenimine Dual-Functionalized Nano-Graphene Oxide for Photothermally Enhanced Gene Delivery. Small 2013; 9: 1989-1997.

35. Bussy C, Ali-Boucetta H, Kostarelos K. Safety Considerations for Graphene: Lessons Learnt from Carbon Nanotubes. Accounts Chem Res 2013; 46: 692-701.

36. Bussy C, Jasim D, Lozano N, Terry D, Kostarelos $K$. The current graphene safety landscape - a literature mining exercise. Nanoscale 2015; 7: 6432-6435.

37. Chen BA, Liu M, Zhang LM, Huang J, Yao JL, Zhang ZJ. Polyethylenimine-functionalized graphene oxide as an efficient gene delivery vector. J Mater Chem 2011; 21: 7736-7741.

38. Kim H, Namgung R, Singha K, Oh IK, Kim WJ. Graphene Oxide-Polyethylenimine Nanoconstruct as a Gene Delivery Vector and Bioimaging Tool. Bioconjugate Chem 2011; 22: 2558-2567.

39. Kim H, Kim WJ. Photothermally Controlled Gene Delivery by Reduced Graphene OxidePolyethylenimine Nanocomposite. Small 2014; 10: 117-126.

40. Paul A, Hasan A, Al Kindi H, Gaharwar AK, Rao VTS, Nikkhah M et al. Injectable Graphene Oxide/Hydrogel-Based Angiogenic Gene Delivery System for Vasculogenesis and Cardiac Repair. ACS nano 2014; 8: 8050-8062.

41. Qin SY, Feng J, Rong L, Jia HZ, Chen S, Liu XJ et al. Theranostic GO-Based Nanohybrid for Tumor Induced Imaging and Potential Combinational Tumor Therapy. Small 2014; 10: 599-608.

42. Ren TB, Li L, Cai XJ, Dong HQ, Liu SM, Li YY. Engineered polyethylenimine/graphene oxide nanocomposite for nuclear localized gene delivery. Polym Chem-Uk 2012; 3: 2561-2569.

43. Xu C, Yang DR, Mei L, Lu BG, Chen LB, Li QH et al. Encapsulating Gold Nanoparticles or Nanorods in Graphene Oxide Shells as a Novel Gene Vector. Acs Appl Mater Inter 2013; 5: 2715-2724.

44. Zhi F, Dong HF, Jia XF, Guo WJ, Lu HT, Yang YL et al. Functionalized Graphene Oxide Mediated Adriamycin Delivery and miR-21 Gene Silencing to Overcome Tumor Multidrug Resistance In Vitro. Plos One 2013; 8. 
45. Zhou X, Laroche F, Lamers GEM, Torraca V, Voskamp P, Lu T et al. Ultra-small graphene oxide functionalized with polyethylenimine (PEI) for very efficient gene delivery in cell and zebrafish embryos. Nano research 2012; 5: 703-709.

46. Tripathi SK, Goyal R, Gupta KC, Kumar P. Functionalized graphene oxide mediated nucleic acid delivery. Carbon 2013; 51: 224-235.

47. Yin D, Li Y, Lin H, Guo BF, Du YW, Li X et al. Functional graphene oxide as a plasmid-based Stat3 siRNA carrier inhibits mouse malignant melanoma growth in vivo. Nanotechnology 2013; 24.

48. Dong HF, Ding L, Yan F, Ji HX, Ju HX. The use of polyethylenimine-grafted graphene nanoribbon for cellular delivery of locked nucleic acid modified molecular beacon for recognition of microRNA. Biomaterials 2011; 32: 3875-3882.

49. Li KY, Feng LZ, Shen JW, Zhang Q, Liu Z, Lee ST et al. Patterned Substrates of Nano-Graphene Oxide Mediating Highly Localized and Efficient Gene Delivery. Acs Appl Mater Inter 2014; 6: 5900-5907.

50. Cheng FF, Chen W, Hu LH, Chen G, Miao HT, Li CZ et al. Highly dispersible PEGylated graphene/Au composites as gene delivery vector and potential cancer therapeutic agent. J Mater Chem B 2013; 1: $4956-4962$.

51. Lungwitz $U$, Breunig M, Blunk T, Gopferich A. Polyethylenimine-based non-viral gene delivery systems. Eur J Pharm Biopharm 2005; 60: 247-266.

52. Feng LZ, Zhang SA, Liu ZA. Graphene based gene transfection. Nanoscale 2011; 3: 1252-1257.

53. Prencipe G, Tabakman SM, Welsher K, Liu Z, Goodwin AP, Zhang L et al. PEG Branched Polymer for Functionalization of Nanomaterials with Ultralong Blood Circulation. Journal of the American Chemical Society 2009; 131: 4783-4787.

54. Dong HF, Dai WH, Ju HX, Lu HT, Wang SY, Xu LP et al. Multifunctional Poly(L-lactide)-Polyethylene Glycol-Grafted Graphene Quantum Dots for Intracellular MicroRNA Imaging and Combined SpecificGene-Targeting Agents Delivery for Improved Therapeutics. Acs Appl Mater Inter 2015; 7: 1101511023.

55. Zhang LM, Wang ZL, Lu ZX, Shen H, Huang J, Zhao QH et al. PEGylated reduced graphene oxide as a superior ssRNA delivery system. J Mater Chem B 2013; 1: 749-755.

56. Bao HQ, Pan YZ, Ping Y, Sahoo NG, Wu TF, Li L et al. Chitosan-Functionalized Graphene Oxide as a Nanocarrier for Drug and Gene Delivery. Small 2011; 7: 1569-1578.

57. Wang CY, Ravi S, Garapati US, Das M, Howell M, Mallela J et al. Multifunctional chitosan magneticgraphene (CMG) nanoparticles: a theranostic platform for tumor-targeted co-delivery of drugs, genes and MRI contrast agents. J Mater Chem B 2013; 1: 4396-4405.

58. Agnihotri SA, Mallikarjuna NN, Aminabhavi TM. Recent advances on chitosan-based micro- and nanoparticles in drug delivery. J Control Release 2004; 100: 5-28. 
59. Kean T, Roth S, Thanou M. Trimethylated chitosans as non-viral gene delivery vectors: Cytotoxicity and transfection efficiency. J Control Release 2005; 103: 643-653.

60. Esfand R, Tomalia DA. Poly(amidoamine) (PAMAM) dendrimers: from biomimicry to drug delivery and biomedical applications. Drug Discov Today 2001; 6: 427-436.

61. Liu XH, Ma DM, Tang H, Tan L, Xie QJ, Zhang YY et al. Polyamidoamine Dendrimer and Oleic AcidFunctionalized Graphene as Biocompatible and Efficient Gene Delivery Vectors. Acs Appl Mater Inter 2014; 6: 8173-8183.

62. Yang HW, Huang CY, Chih-Wen L, Liu HL, Huang CW, Liao SS et al. Gadolinium-functionalized nanographene oxide for combined drug and microRNA delivery and magnetic resonance imaging. Biomaterials 2014; 35: 6534-6542.

63. Imani R, Emami SH, Faghihi S. Synthesis and characterization of an octaarginine functionalized graphene oxide nano-carrier for gene delivery applications. Phys Chem Chem Phys 2015; 17: 63286339.

64. Yang XC, Zhao NN, Xu FJ. Biocleavable graphene oxide based-nanohybrids synthesized via ATRP for gene/drug delivery. Nanoscale 2014; 6: 6141-6150.

65. Fukuda S, Pelus LM. Survivin, a cancer target with an emerging role in normal adult tissues. Mol Cancer Ther 2006; 5: 1087-1098.

66. Wang Y, Li ZH, Hu DH, Lin CT, Li JH, Lin YH. Aptamer/Graphene Oxide Nanocomplex for in Situ Molecular Probing in Living Cells. Journal of the American Chemical Society 2010; 132: 9274-9276.

67. Choi HY, Lee TJ, Yang GM, Oh J, Won J, Han J et al. Efficient mRNA delivery with graphene oxidepolyethylenimine for generation of footprint-free human induced pluripotent stem cells. $J$ Control Release 2016; 235: 222-235.

68. Huang YP, Hung CM, Hsu YC, Zhong CY, Wang WR, Chang CC et al. Suppression of Breast Cancer Cell Migration by Small Interfering RNA Delivered by Polyethylenimine-Functionalized Graphene Oxide. Nanoscale Res Lett 2016; 11: 247.

69. Zhang W, Guo ZY, Huang DQ, Liu ZM, Guo X, Zhong HQ. Synergistic effect of chemo-photothermal therapy using PEGylated graphene oxide. Biomaterials 2011; 32: 8555-8561.

70. Imani R, Shao W, Taherkhani S, Emami SH, Prakash S, Faghihi S. Dual-functionalized graphene oxide for enhanced siRNA delivery to breast cancer cells. Colloids Surf B Biointerfaces 2016; 147: 315-325. 


\section{Table 1}

\begin{tabular}{|c|c|c|c|c|c|}
\hline GBM & NA & $\begin{array}{l}\text { Additional chemical } \\
\text { functionalisation }\end{array}$ & $\begin{array}{l}\text { Cell line / } \\
\text { tissue }\end{array}$ & Application & Ref \\
\hline $\begin{array}{l}\text { Graphene } \\
\text { GO }\end{array}$ & pDNA & $\begin{array}{c}\text { PAMAM (covalent binding via 1,3 dipolar } \\
\text { cycloaddition) } \\
\text { Oleic acid (adsorption) }\end{array}$ & $\begin{array}{c}\text { HeLa } \\
\text { epithelial } \\
\text { MG63 } \\
\text { fibroblast }\end{array}$ & $\begin{array}{c}\text { Expression of } \\
\text { exogenous genes } \\
(\text { EGFP) }\end{array}$ & 6T \\
\hline GO & MB & $\mathrm{N} / \mathrm{A}$ & $\begin{array}{l}\text { HeLa } \\
\text { epithelial }\end{array}$ & $\begin{array}{l}\text { Molecular sensing } \\
\text { (survivin) }\end{array}$ & 24 \\
\hline GO & $\begin{array}{l}\text { DNA } \\
\text { aptamer }\end{array}$ & N/A & $\begin{array}{c}\text { JB6 } \\
\text { epithelial }\end{array}$ & $\begin{array}{l}\text { Molecular sensing } \\
\text { (ATP) }\end{array}$ & 66 \\
\hline GO & pDNA & $\begin{array}{c}\text { Chitosan (covalent binding, EDC/NHS } \\
\text { chemistry) } \\
\text { Campthotecin ( } \pi-\pi \text { stacking) }\end{array}$ & $\begin{array}{c}\text { HeLa } \\
\text { epithelial }\end{array}$ & $\begin{array}{l}\text { Expression of } \\
\text { exogenous genes } \\
\text { (luciferase) }\end{array}$ & 56 \\
\hline GO & pDNA & $\begin{array}{c}25 \mathrm{kDa} \text { branched PEI (covalent binding via } \\
E D C / \text { NHS chemistry) }\end{array}$ & $\begin{array}{l}\text { HeLa } \\
\text { epithelial }\end{array}$ & $\begin{array}{l}\text { Expression of } \\
\text { exogenous genes } \\
\text { (EGFP) }\end{array}$ & 37 \\
\hline GO & pDNA & $\begin{array}{c}1.2 \text { and } 10 \mathrm{kDa} \text { branched PEI (adsorption via } \\
\text { electrostatic interactions) }\end{array}$ & $\begin{array}{l}\text { HeLa } \\
\text { epithelial }\end{array}$ & $\begin{array}{l}\text { Expression of } \\
\text { exogenous genes } \\
\text { (EGFP) }\end{array}$ & 52 \\
\hline GO & pDNA & $\begin{array}{c}\text { Octaarginine (covalent binding via EDC/NHS } \\
\text { chemistry) }\end{array}$ & $\begin{array}{l}\text { LS29 } \\
\text { fibroblast }\end{array}$ & $\begin{array}{l}\text { Expression of } \\
\text { exogenous genes } \\
(E G F P)\end{array}$ & 63 \\
\hline GO & pDNA & $\begin{array}{c}10 \text { and } 25 \mathrm{kDa} \text { PEI (covalent binding via } \\
\text { EDC/NHS chemistry) } \\
\text { Nuclear localised signals PV7 peptide } \\
\text { (hydrogen binding and electrostatic } \\
\text { interactions) }\end{array}$ & $\begin{array}{l}\text { Hela } \\
\text { epithelial } \\
\text { HEK293 } \\
\text { epithelial }\end{array}$ & $\begin{array}{l}\text { Expression of } \\
\text { exogenous genes } \\
(\text { (EGFP) }\end{array}$ & 42 \\
\hline GO & pDNA & $\begin{array}{c}\text { PDMAEMA (covalent binding via EDC/ NHS } \\
\text { chemistry) } \\
\text { Camptothecin (adsorption) }\end{array}$ & $\begin{array}{l}\text { COS7 } \\
\text { fibroblast } \\
\text { HepG2 } \\
\text { epithelial }\end{array}$ & $\begin{array}{l}\text { Expression of } \\
\text { exogenous genes } \\
\text { (luciferase) }\end{array}$ & ${ }^{64} \mid$ \\
\hline GO & pDNA & $\begin{array}{c}60 \mathrm{kDaPEI} \text { (covalent binding via carbodiimide } \\
\text { crosslinking reaction) }\end{array}$ & $\begin{array}{c}\text { HEK293 } \\
\text { epithelial } \\
\mathrm{U}_{2} \mathrm{Os} \\
\text { epithelial } \\
\text { Zebrafish } \\
\text { embryo }\end{array}$ & $\begin{array}{l}\text { Expression of } \\
\text { exogenous genes } \\
(E G F P)\end{array}$ & 45 \\
\hline GO & pDNA & 25 kDa PEI (adsorption) & $\begin{array}{c}\text { HeLa } \\
\text { epithelial } \\
\text { HEK293 } \\
\text { epithelial } \\
\text { hMSC }\end{array}$ & $\begin{array}{c}\text { Expression of } \\
\text { exogenous } \\
\text { genes/substrate } \\
\text { mediated } \\
\text { (EGFP, luciferase) }\end{array}$ & 49 \\
\hline GO & pDNA & $\begin{array}{c}1.8 \mathrm{kDa} \text { branched PEI (covalent binding via } \\
E D C / N H S \text { chemistry) }\end{array}$ & $\begin{array}{l}\text { Rat heart after } \\
\text { myocardial } \\
\text { infarction }\end{array}$ & $\begin{array}{c}\text { Expression of } \\
\text { exogenous gene with } \\
\text { therapeutic aim (VEGF, } \\
\text { angiogenesis) }\end{array}$ & 40 \\
\hline GO & pDNA & $\begin{array}{l}1.8 \text { and } 25 \mathrm{kDa} \text { branched PEI (covalent } \\
\text { binding via EDC/NHS chemistry) }\end{array}$ & $\begin{array}{l}\text { HeLa } \\
\text { Epithelial } \\
\text { PC-3 } \\
\text { epithelial }\end{array}$ & $\begin{array}{l}\text { Expression of } \\
\text { exogenous genes and } \\
\text { bioimaging (luciferase) }\end{array}$ & 38 \\
\hline GO & pDNA & $\begin{array}{l}5 \mathrm{kDa} \text { branched PEI and } 526 \text { Da PEG } \\
\text { (covalent binding via EDC/NHS chemistry) } \\
\text { Doxorubicin (covalent binding via MMP2- } \\
\text { cleavable PLGLAG peptide linkage) }\end{array}$ & $\begin{array}{c}\text { HeLa } \\
\text { epithelial } \\
\text { HEK293 } \\
\text { epithelial } \\
\text { COS7 } \\
\text { fibroblast }\end{array}$ & $\begin{array}{c}\text { Theranostic (luciferase, } \\
\text { doxorrubicin) }\end{array}$ & 41 \\
\hline GO & $\begin{array}{l}\text { pDNA } \\
\text { siRNA }\end{array}$ & $\begin{array}{l}\text { Linear-PEI (covalent binding through epoxy } \\
\text { ring opening) }\end{array}$ & $\begin{array}{l}\text { HeLa } \\
\text { epithelial } \\
\text { HEK293 } \\
\text { epithelial }\end{array}$ & $\begin{array}{c}\text { Expression of } \\
\text { exogenous genes } \\
\text { (EGFP) } \\
\text { Gene silencing } \\
\text { (EGFP) }\end{array}$ & 46 \\
\hline
\end{tabular}




\begin{tabular}{|c|c|c|c|c|c|}
\hline & \multicolumn{4}{|c|}{ ACCEPIED ARTICL를 PRVIEN } & \\
\hline GO & pDNA siRNA & $\begin{array}{c}10 \mathrm{kDa} \text { PEG and 25k Da branched PEI } \\
\text { (covalent binding via EDC/ NHS chemistry) }\end{array}$ & $\begin{array}{c}\text { HeLa } \\
\text { epithelial }\end{array}$ & $\begin{array}{l}\text { Photothermally } \\
\text { controlled expression } \\
\text { of exogenous gene } \\
\text { (EGFP) and gene } \\
\text { silencing (Plk-1) }\end{array}$ & \\
\hline GO & $\begin{array}{l}\text { Plasmid - } \\
\text { siRNA }\end{array}$ & $\begin{array}{c}1.2 \mathrm{kDa} \text { PEI (covalent binding via EDC/ NHS } \\
\text { chemistry) } \\
5 \mathrm{kDa} \text { PEG (covalent binding via EDC/ NHS } \\
\text { chemistry) }\end{array}$ & $\begin{array}{c}\text { B16 } \\
\text { spindle- } \\
\text { shape/epithelial } \\
\text { B16 allograft }\end{array}$ & Gene silencing (Stat3) & 41 \\
\hline GO & siRNA & $\begin{array}{c}25 \mathrm{kDa} \text { branched PEI (covalent binding via } \\
E D C / \text { NHS chemistry) }\end{array}$ & $\begin{array}{l}\text { MDA-MB-231 } \\
\text { epithelial }\end{array}$ & Gene silencing (CXCR4) & 68 \\
\hline GO & siRNA & $\begin{array}{c}25 \mathrm{kDa} \text { PEI (covalent binding via EDC/NHS } \\
\text { chemistry) } \\
\text { DOX (adsorption) }\end{array}$ & $\begin{array}{l}\text { HeLa } \\
\text { epithelial }\end{array}$ & $\begin{array}{l}\text { Gene silencing }(\mathrm{Bcl}-2) \\
\text { and drug delivery } \\
\text { (doxorubicin) }\end{array}$ & 69 \\
\hline GO & siRNA & $\begin{array}{c}25 \mathrm{kDa} \text { PEI/ PSS (layer-by-layer assembly } \\
\text { method) } \\
\text { Adriamycin (physisorption) }\end{array}$ & $\begin{array}{l}\text { MCF7 } \\
\text { epithelial } \\
\text { (adriamycin- } \\
\text { resistant and } \\
\text { non-resistant) }\end{array}$ & $\begin{array}{l}\text { Gene silencing (miR-21) } \\
\text { and drug delivery } \\
\text { (adryamicin) }\end{array}$ & 44 \\
\hline GO & $\begin{array}{l}\text { Total RNA } \\
\text { mRNA }\end{array}$ & 25 kDaPEI (adsorption) & $\begin{array}{l}\text { Human and rat } \\
\text { adipose tissue- } \\
\text { derived } \\
\text { fibroblasts } \\
\text { (hADFs, rADFs) }\end{array}$ & $\begin{array}{l}\text { Expression of } \\
\text { exogenous genes } \\
\text { (reprogramming factors: } \\
\text { Oct3/4, So2, Klf4, cMyc) }\end{array}$ & 61 \\
\hline & & & $\begin{array}{l}\text { Mouse } \\
\text { embryonic } \\
\text { fibroblasts } \\
\text { (MEFs) }\end{array}$ & & \\
\hline $\begin{array}{l}\text { GO } \\
\text { rGO }\end{array}$ & ssRNA & $\begin{array}{c}10 \mathrm{kDa} \text { PEG (covalent binding via EDC/NHS } \\
\text { chemistry) }\end{array}$ & $\begin{array}{l}\text { HeLa } \\
\text { epithelial }\end{array}$ & $\begin{array}{l}\text { Transfer of NA } \\
\text { (application not defined) }\end{array}$ & bs \\
\hline rGO & pDNA & $\begin{array}{c}1.8 \mathrm{kDa} \text { branched PEI (covalent binding via } \\
\text { EDC/ NHS chemistry) } \\
5 \mathrm{kDa} \text { PEG (covalent binding simultaneously } \\
\text { with hydrazine reduction) }\end{array}$ & $\begin{array}{l}\mathrm{NIH} / 3 \mathrm{~T} 3 \\
\text { fibroblast } \\
\text { PC-3 } \\
\text { epithelial }\end{array}$ & $\begin{array}{l}\text { Photothermally } \\
\text { controlled expression } \\
\text { of exogenous gene } \\
\text { (luciferase) }\end{array}$ & 39 \\
\hline rGO & siRNA & $\begin{array}{c}\text { PL-PEG (adsorption) } \\
\text { Octaarginine (adsorption) }\end{array}$ & $\begin{array}{l}\text { MCF7 } \\
\text { epithelial }\end{array}$ & $\begin{array}{l}\text { Gene silencing } \\
\text { (cell death siRNA) }\end{array}$ & 70 \\
\hline $\begin{array}{l}\text { GO-AuNP } \\
\text { GO-AuNR }\end{array}$ & pDNA & $\begin{array}{c}25 \mathrm{kDa} \text { PEI (covalent binding via EDC/NHS } \\
\text { chemistry) } \\
\text { Encapsulation of Au NP and NR through } \\
\text { electrostatic self-assembly }\end{array}$ & $\begin{array}{l}\text { HeLa } \\
\text { epithelial }\end{array}$ & $\begin{array}{l}\text { Expression of } \\
\text { exogenous genes } \\
(\text { EGFP) }\end{array}$ & 43 \\
\hline Gd-GO & $\begin{array}{l}\text { pDNA } \\
\text { miRNA }\end{array}$ & $\begin{array}{l}\text { PAMAM dendrimer (covalent binding via EDC/ } \\
\text { NHS chemistry) } \\
\text { Gadolinium (covalent binding via EDC/ NHS } \\
\text { chemistry) } \\
\text { Epirubicin (adsorption) }\end{array}$ & $\begin{array}{c}\text { U87 } \\
\text { epithelial } \\
\text { In vivo brain } \\
\text { tumor model } \\
\text { mouse }\end{array}$ & $\begin{array}{l}\text { Theranostic } \\
\text { (EGFP, Let-7g miRNA, } \\
\text { epirubicin, MRI) }\end{array}$ & 62 \\
\hline $\mathrm{rGO} / \mathrm{Au}$ & siRNA & $\begin{array}{c}25 \mathrm{kDa} \text { branched PEI (adsorption through } \\
\text { electrostatic interactions) } \\
\text { Methoxyl-PEG (covalent binding via amidation } \\
\text { reaction) }\end{array}$ & $\begin{array}{c}\mathrm{HL}-60 \\
\text { promyeloblast }\end{array}$ & $\begin{array}{l}\text { Gene silencing } \\
\text { (Bcl-2) }\end{array}$ & 50 \\
\hline rGO/SPIOs & pDNA & $\begin{array}{c}70 \text { kDa PSS (covalent linkage simultaneously } \\
\text { with hydrazine reduction) } \\
\text { Chitosan (covalent binding via EDC/ NHS } \\
\text { chemistry) } \\
\text { Doxorubicin (adsorption) } \\
\text { Superparamagnetic iron oxide (adsorption) }\end{array}$ & $\begin{array}{c}\text { PC-3 } \\
\text { epithelial } \\
\text { A459 } \\
\text { epithelial } \\
\text { LLC1 xenograft }\end{array}$ & $\begin{array}{c}\text { Theranostic } \\
\text { (EGFP, doxorrubicin, } \\
\text { MRI) }\end{array}$ & 57 \\
\hline GNR & MB & $\begin{array}{l}25 \mathrm{kDa} \text { PEI (non- covalent binding via } \\
\text { electrostatic interactions) }\end{array}$ & $\begin{array}{l}\text { HeLa } \\
\text { epithelial }\end{array}$ & $\begin{array}{l}\text { Molecular sensing } \\
\text { (miRNA sensing) }\end{array}$ & 48 \\
\hline GQDs & $\begin{array}{l}\text { MB } \\
\text { RNAi } \\
\text { (not } \\
\text { specified) }\end{array}$ & $\begin{array}{c}2 \mathrm{kDa} \text { PEG (covalent binding, EDC chemistry) } \\
\text { Poly(L-lactide) (covalent binding, EDC/ NHS } \\
\text { chemistry) }\end{array}$ & $\begin{array}{l}\text { HeLa } \\
\text { epithelial }\end{array}$ & $\begin{array}{l}\text { Molecular sensing } \\
\quad \text { (miRNA-21) } \\
\text { Gene silencing } \\
\text { (miR-21, survivin) } \\
\end{array}$ & 54 \\
\hline
\end{tabular}




\section{ACCEPTED ARTICLE PREVIEW}

\section{Table 2}

Modification strategy positively-charged polymers (PEI, BPEI) and dendrimers (PAMAM)
Advantages

Limitations

- Enhances electrostatic interactions with NA (complexation)

- Favours electrostatic adhesion onto cell membrane (binding)

- Promotes endosomal release

- Increased cytotoxicity compared to non-cationic vectors

Allows use of low molecular weigh cationic polymers and dendrimers (reduced cytotoxicity)

- Enhances aqueous dispersibility

Decoration with positively-charged polysaccharides (chitosan)

- $\quad$ Reduced cytotoxicity compared to PEI and PAMAM

- Increased circulation time in vivo

- Enhanced biocompatibility

- Restores aqueous dispersibility of rGO

- Enhanced internalization and transfection efficiency

\section{penetrating peptides}

- Enhanced AuNP aqueous dispersibility

- Sinergistic photothermal effect

- Targets tumor cells
- Lower transfection efficiency compared to $\mathrm{PE}$

- Increased surface complexity

- Shielding of the carbon backbone

- Interactions with the PEG surface layer

Decreased aqueous dispersibility of the complexes when functionalization ratios are high

- Requires PEI or PEG for sufficient transfection efficiency

\section{Tumor-specific cleavable} links
- Off-target effects need to be investigated 


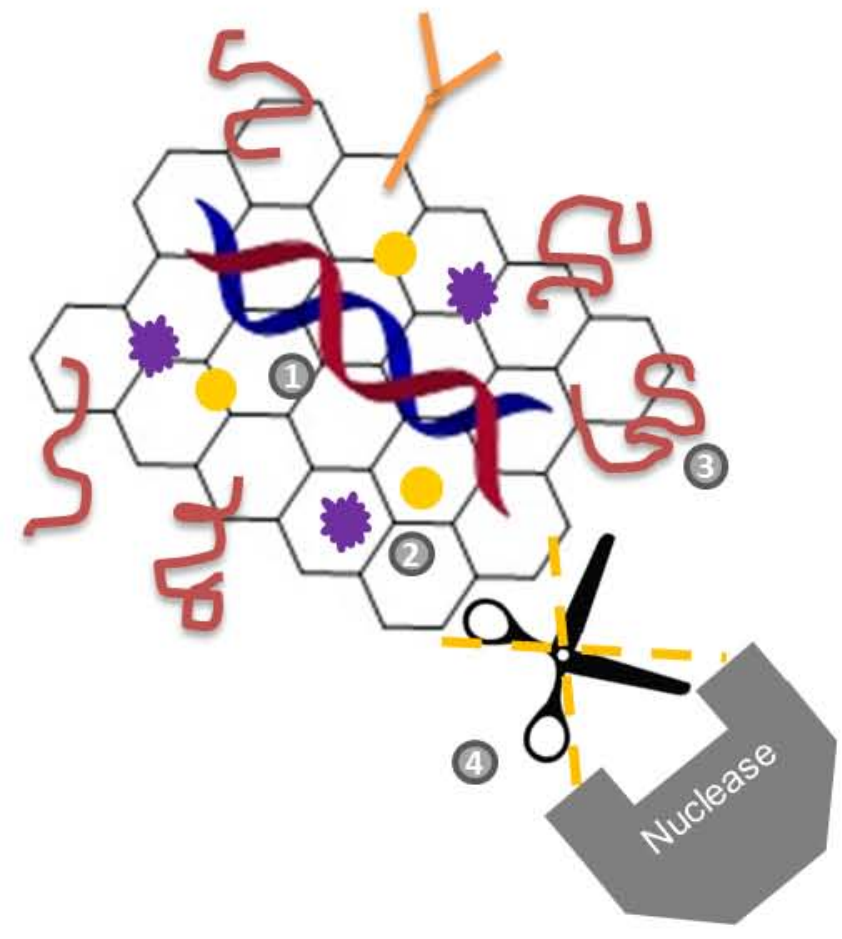

\section{A. Vector design}

(1) Ability to load single and double stranded NA

(2) Theranostics: incorporation of drugs and imaging agents

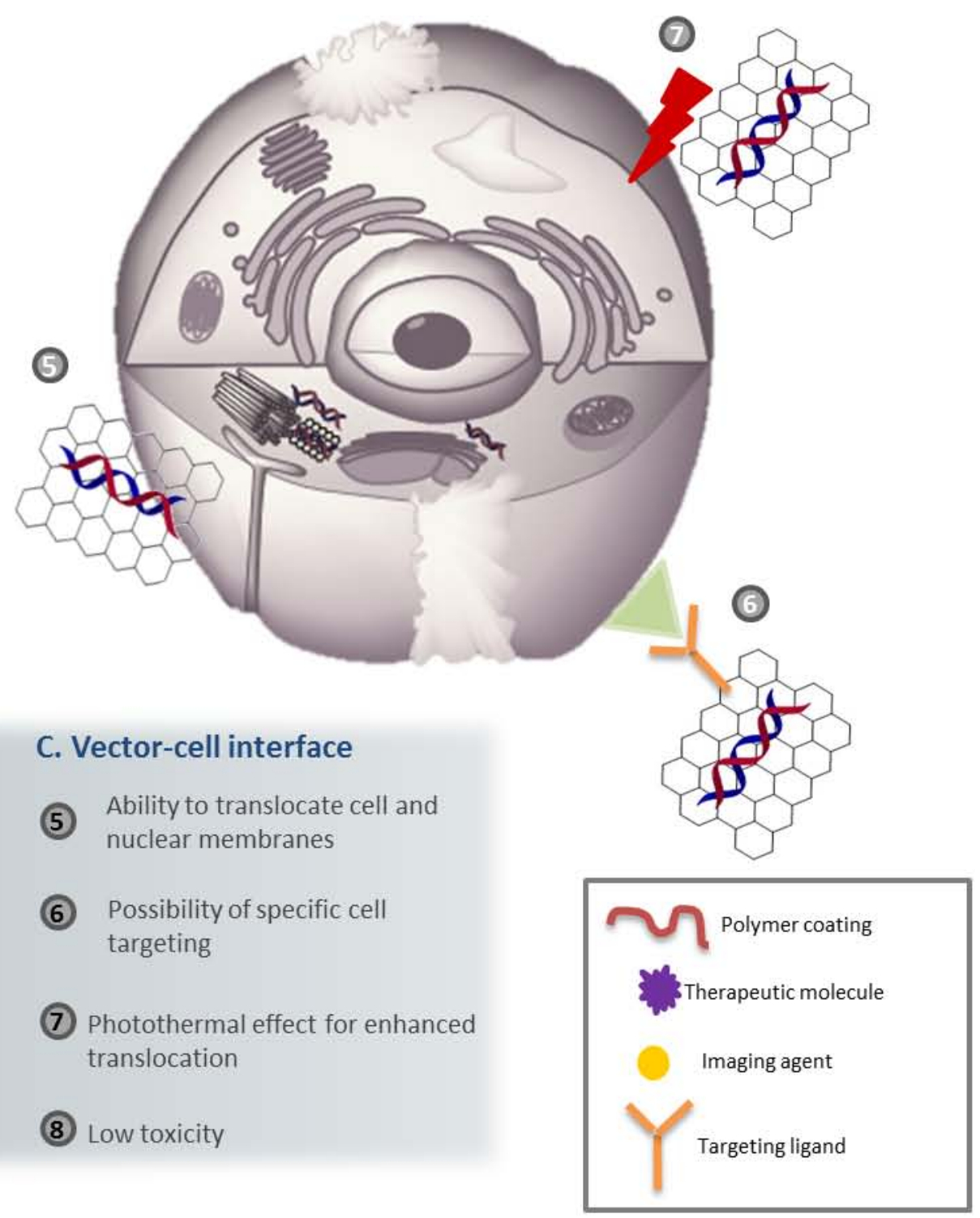

Figure 1 


\section{Macromolecular Shielding Layer a PEI, PEG, PSS, chitosan, PDMAEMA}

Chemical Modification Strategies

$\$$ EDC/NHS chemistry

*Adsorption

* Cleavable disulphide bonds

\section{Therapeutic, Contrast}

or Imaging Cargos

\section{Aims.}

* Positive charge increases NA loading efficiency

* Managed cytotoxicity

* Improved stability in saline and cell medium

- Doxorubicin, camptothecin, epirubicin

Gadolinium, SPIO

Eluorescently labelled aptamers, molecular beacons

\section{Chemical Modification Strategies}

* EDC/ NHS chemistry-

* Adsorption

\section{Aim}

* Theranostics allowing both imaging

capability and therapeutic activity

Membrane Penetrating

\section{Peptides}

Octaarginine, nuclearlocalisation sequence

aleicacid

Chemical Modification Strategies

*Adsorption

\&DC/NHS chemistry

Aim

* Enhanced cellular/ nuclear uptake 


\section{Gene silencing}

(siRNA, other RNAi not specified)

Expression of exogenous genes ( $p D N A$, miRNA, mRNA)

Intracellular molecular sensing (MB, DNA aptamer)

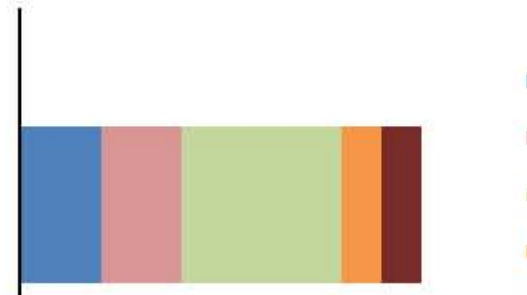

- Combined with drug delivery

- Combined with heat-induced cytotoxicity

* siRNA/antisense probe only

* Theranostic (with drug and imaging agent)

- Photothermally-controlled

- Substrate-mediated

= Therapeutic gene product

= Theranostic (with drug and imaging agent)

- Combined with bioimanging

- Photothermally-controlled

- Proof of principle

Reprogramming gene product

\section{Number of publications (2010-2016)}

